JANINA STANKIEWICZ

PATRYCJA ŁYCHMUS

\title{
Ethical choices and behavior of young people in the organization; influencing factors
}

The article realized with the financial support of the City of Zielona Gora

\section{Introduction}

Many authors (Kopycińska 2001; LewickaStrzałecka 2006; Lewicka-Strzałecka 1999; Nogalski, Śniadecki 2001; Porębski 1997; Rybak 2004; Sternberg 1998; Sułek, Świniarski 2001) emphasize in their studies that one of the essential conditions for growth and success in business is fair, responsible, decent and, by implication, ethical conduct of the people involved in it. According to them, knowledge and use of business ethics can serve in more effective achievement of companies' goals and interests - manifestation of ethical responsibility by the participants may result in business optimization and thus increase the quality of the organization on the market. Business ethics can also streamline management by providing tools to help today's leaders exercise ethical leadership. As a result, reduced may be the costs of possible conflicts arising from the ignorance of the

Professor Janina Stankiewicz University of Zielona Góra Patrycja Łychmus, Ph. D. University of Zielona Góra applicable morality rules (Ryan, Sójka 1997; Szulczewski 2008).

The theses quoted in many cases find no support in reality. Today's business world 
provides many examples of the gap existing between the theoretical approach and the economic reality. Noticeable liberalization of ethical criteria and standards in market activity makes the recognized principles relative rather than unambiguous, which can lead to fraud, corruption and scandals in the face of which both society and the authorities are helpless.

What is the reason for this ethical paradox? What causes the mentioned gap between theory and real-life management? It is a truism to say that this is due, inter alia, to attitudes towards business ethics held by the people who shape the labor market (both employers and employees). Although each of them is a "follower" of a certain ethics formed during their respective educational process, founded on the values declared not only in professional but also everyday life, they may as well follow different ethics based on the values practiced. The first ethics can be called "ideal" (being the sum of what individuals deem good), while the second one - "real" (being practical fulfillment of ideals). They both differ in so far as the values declare differ from those that are practiced (Kubik 2013). Questions arise: what factors control the behavior of people involved in business activities in a situation of choice between ethical and cost-effective action, and how important is ethics of individuals when they are making this kind of decision? From this perspective interesting are those who "have not yet entered the labor market", and therefore their individual ethics has not been subjected to the pressure of business practice in its ethical and unethical dimension. These people are part

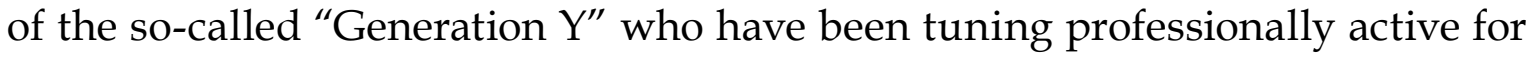
the last few years. As indicated by the forecasts, the number of this generation's representatives in enterprises will increase steadily (Generacja Y..., 2016). These are the people who grew up in a specific environment, constituting the first generation of Poles who were brought up in peace and were subjected to the conditions of capitalistic economy (Fazlagić 2016), which affects the values that they are motivated by as well as the expectations they have towards professional reality. What are their opinions on business ethics? What values in business are important to them? The answers to these questions became the main focus of this article.

\section{Prospects of business ethics recognition; their assumptions in terms of the factors determining ethical choices and behavior of people in the work environment}

The leading ethical systems, referred to by Polish business ethicists deontologism, utilitarianism, ethics of responsibility and virtue ethics - as 
argued by A. Zadroga, present a different prospect of developing, justifying, teaching and practicing ethics (Zadroga 2009).

Deontological business ethics (also known as ethics of principles or formal ethics) assumes that the basis of one's consciousness and moral reasoning are prohibitions and orders constituting a form of regulating their behavior (Wiśniewski 1997). As per this approach, what regulates the moral conduct of employees are codes of ethics determining the scope of responsibilities and duties to be managed in order to fulfill one's professional obligations. These codes also provide a formal basis to enforce conduct that is deemed as violating the image of the profession or the company (Wiśniewski 1997).

Ethical utilitarianism is concept assuming that all people are equal and equally important. In line with its recommendations, employees should act so as to optimize the balance of the system within which activities take place. In contrast to the classical, hedonistic utilitarianism, the calculation mechanism is here transferred to the plane of values (Wiśniewski 1997). However, as emphasizes B. Klimczak (2003), problematic in this approach is that, in assessing the moral conduct of an employee, one accounts only for the outcome, not the person and their motives. According to utilitarianism, the individual is prone to ethical conduct only because "ethics pays off", which makes morality instrumental.

Unlike the two approaches presented above, ethics of responsibility focuses on man, their experience of their own dignity and that of others, honest (conscientious, responsible) relationship with every business partner as a human being, as well as work deemed as interpersonal relations. Referring to the theory of moral development (including Piaget, Kohlberg (Fleming 2016; Siegal 2016)), it is assumed that the highest (and therefore desirable) level of moral maturity "conscientious auto-regulation of conduct." Only a "conscientious" person, says R. Wisniewski, may be responsible, whereas professional competence must go hand in hand with moral competence.

Virtue ethics refers to the concept of Aristotle, who understood virtue to be a moral advantage (in the narrower sense), but also (in the broader sense) a permanent disposition to appropriate action performed in accordance with reason (Tomczyk-Tołkacz 2000; Klimczak 1999; Zadroga 2009). Considering the possibilities of creating employees' ethical behavior, one can - as per J. TomczykTołkacz - state that "to organize and improve the professional practice of people, also in business, mere rules of validation or effectiveness are not enough necessary are also, and perhaps above all, special human dispositions. These dispositions are nothing more than virtues" (Tomczyk-Tołkacz 2000). The author 
in question points mostly to wisdom and justice, and she believes the most important virtue in business is sincerity in the realm of intentions, declarations, actions (including competition), settlements and negotiations.

The four theoretical approaches presented indicate the need to seek clarification on the factors determining the behavior of people involved in business activities, in particular in a situation of choice between an ethical and cost-effective action. Assuming that each of them can become an inspiration to create solutions that constitute ethics in the organization, it is worth enriching the analysis with additional assumptions regarding human nature. A. Lewicka-Strzałecka speaks of at least two different stands on this issue (Lewicka-Strzałecka 1997; Zadroga 2009). The first assumes that human decisions are determined by external conditions. From this standpoint, factors influencing unethical behavior of an employee include: lack of competition, information asymmetry, randomness of transactions. The second stand, meanwhile, holds that a person is autonomous and responsible in their choices, and decisions about their own behavior are taken by him or her freely, in accordance with the established hierarchy of values. For this reason it is not possible to influence their ethical choices simply by creating favorable situational (organizational) factors.

Echoing this perspective, we note that the purpose of introducing and promoting ethics in the organization is primarily to support those employees who wish to remain sincere, in spite of the circumstances which lead them astray, not to convert "sinners." Whenever an employee knowingly and voluntarily decides to cheat tax authorities, customers, suppliers or colleagues, they will not be hindered by the institutionalization of ethics in the enterprise that employs him. Such behavior can be prevented by law and a good control system. Dissemination of ethics in the company is helpful to those who already hold a set of ethical beliefs and values, but forget them - or interpret them with haste or bias - under adverse circumstances or complexity of the economic process (Kubik 2013).

Given the assumption, it can be argued that formal regulations of employees' behavior that exist in the organization (e.g. in the form of institutional or proethical organizational culture) may encourage the ethical conduct among workers, although the necessary backbone for moral behavior lies in personal ethical systems (Figure 1), which are formed from an early age. This process involves: educational environment (including family and the religious system it follows), cultural surroundings, peer and reference groups, educational institutions (kindergarten, school, university and, at the professional stage, organizations) (Borkowski 2009). 


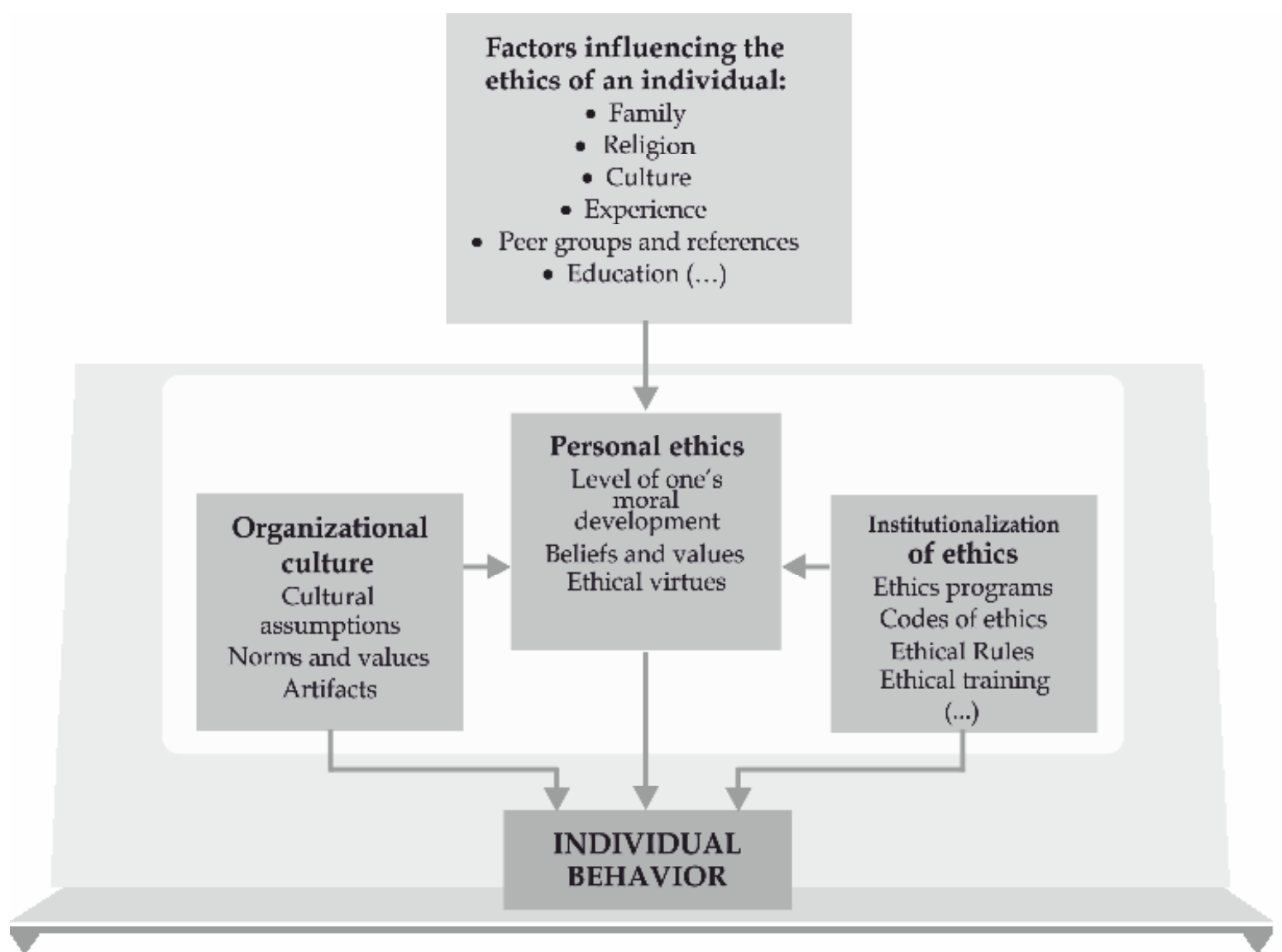

Figure 1. Factors influencing ethical choices and behavior of organization members

Source: own study

Moral education of adults in the organization is - in the light of the reflections at hand - an action that is significantly delayed, and thus may be not only timeconsuming, but also very difficult. The rules of ethical conduct in business such as respecting people, truthfulness, not exploiting others, fulfilling duties, respecting certain contract conditions etc. - should be instilled much earlier than by the time one starts their professional career (Borkowski 2009). Thus, what ethical standards do people who enter the labor market and start a career (i.e. Generation Y) have? Or more specifically: what are their thoughts on business ethics? Recall that this community is particularly interesting since, on the one hand, their personal ethics has yet to be modified by the use of formal, often imposed, ethical standards of the organization, while on the other hand, it is this group who will shape the future labor market, replacing "old" values and 
ethical standards, typical of people who are currently professionally active, with "new" ones.

\section{Characteristics of the sample, research methodology and its course}

The research was conducted in 2015 and comprised all third-year undergraduate students of Economics ( 89 people) and Management (59 people). Selection of respondents was dictated by two things. First, some of them had recently become active participants of the labor market, while the others were to begin their professional career soon ${ }^{1}$. Second, following professional paths of the graduates, it could be noticed that part of them had decided to start their own business shortly after graduation ${ }^{2}$. This trend has been persisting for years, so that it can be assumed that in the case of the research sample in question the results will be similar. They will, therefore, become the creators of paradigms used in the practice of their own businesses, which may (or may not) contain the imperative of applying business ethics. Among the respondents, there were 113 women and 35 men, all aged between 22 and 23. The disproportion between the number of women and men was due to the population structure of Polish students. As can be seen from the statistics, compared with men, women are more likely to finish their studies and they make up for as much as $64 \%$ of all Masters degrees obtained in Poland (Coraz więcej kobiet w nauce... 2016).

The study proceeded in two stages. The first stage was carried out in November 2015 when written opinions on business ethics were obtained from the respondents. They were not previously informed that they would be research participants; neither detailed was the range of responses or time to complete the task. Apart from that, they were not bound by time in their responses. The only limitation was the place of conducting the survey, held in the presence of the author, which enabled supervision over the process of opinion formation and

1 As follows from Raport $z$ monitoringu karier zawodowych absolwentów Wydziału Ekonomii i Zarzadzania (2014) prepared by Dr. Eng. P. Łychmus, based on the study entitled Wizerunek Uniwersytetu Zielonogórskiego, ocena efektów ksztatcenia oraz własnej aktywności ekonomicznej w przekonaniach absolwentów (2014) by J. Leszkowicz-Baczyński and D. Szaban, more than a fifth of the respondents (22.4\%) showed rationality involving the early search of employment - up to 6 months before defending a diploma - while every twelfth (8.6\%) began looking for work earlier than 6 months after graduation. Such trends over several years persist, which is why it was assumed that they related to the student sample in the research at hand.

2 According to the report (Raport $z$ monitoringu ..., op. cit.), within six months after graduation, every fifth of the surveyed graduates (20.0\%) started their own business (self-employment). 
also created the opportunity to observe individual respondents and record the time they needed to complete the task. This allowed for an estimated assessment of the respondents' autonomy in the course of formulating statements, as well as their level of involvement. Necessary steps were taken to ensure that the researcher's supervision was discreet enough not to disturb the respondent's freedom of expression.

The second research stage - elaboration of the results obtained - took place in December 2015. The opinions received were in the form of unrestricted statements expressed in writing. They were therefore categorized and arranged based on content. Distinguished were 23 categories of statements, which were then assigned them to individual respondents. This aggregated data was later analyzed both qualitatively and quantitatively.

\section{Young people's opinions about business ethics}

The majority of the respondents $(89.19 \%)$ took a "pro-ethical" stand, i.e. every ninth person was "for" business ethics (Table 1). The rest expressed an ambiguous opinion (they were both "for" and "against" ethics - 7.43\%) or claimed that business ethics did not exist - $4.73 \%$. The statements do not add up to $100 \%$ because there were some respondents who were "for" ethics, but stressed that there was no place for it in today's economic reality. Despite the observed differences, the obtained picture is optimistic - perhaps the majority of the respondents having a positive attitude towards business ethics will be a predictor of manifestation of ethical behavior in the course of one's career. There is, however, a danger that in the future those people will face a situation where they will be urged to act without scruples and compassion for others. As pointed out by T. Borkowski: "Even those authors who are great supporters of ethics in business admit that profit, competition, self-interest, success are the foundation of a healthy economy" (Borkowski 2009). This can lead to extremely selfish attitudes of the market participants, whose sole purpose is to maximize profit, without regard for costs and losses in the immaterial sphere. The functioning of the organizations that promotes such business optics, forces its members to modify and even distort their own hierarchy of values. Even an individual with a well-constituted system of values is prone to peer pressure, prompting them to unethical actions. It often happens that one then acts contrary to their personal principles (Mesjasz 2003). And despite the initial psychological discomfort and a sense of shame they begin to find their way in the world of tough and merciless rules that violate basic ethical standards. The obtained research results show that 
the respondents are probably aware of such risks, or at least notice that there are companies or people who do not respect moral principles in their professional practice $(25.00 \%)$. Some of them $(12.16 \%)$ gave examples of such cases. They were usually drawn from personal experience or observations related to student internships and temporary jobs taken up during semester breaks.

Table 1. Respondents' opinions about business ethics (in \%)

\begin{tabular}{|c|c|c|}
\hline & Response categories & Total (in\%) \\
\hline 1 & Being „for" ethics & 89.19 \\
\hline 2 & Written from the perspective of employees (mentions about employees) & 45.95 \\
\hline 3 & $\begin{array}{l}\text { Written from the perspective of clients/customers (mentions about clients/ } \\
\text { customers) }\end{array}$ & 27.03 \\
\hline 4 & $\begin{array}{l}\text { Being "for" ethics, but acknowledging there are companies (people) who do } \\
\text { not comply with its rules }\end{array}$ & 25.00 \\
\hline 5 & $\begin{array}{l}\text { Indicating that the use of ethics means establishing rules / associating ethics } \\
\text { with adherence to rules (code of ethics) }\end{array}$ & 23.65 \\
\hline 6 & Written from the perspective of the company (mentions about the company) & 22.30 \\
\hline 7 & Emphasizing the importance of personal ethics & 18.24 \\
\hline 8 & Presenting the advantages of being ethical & 17.57 \\
\hline 9 & Written from the perspective of contractors (mentions about contractors) & 15.54 \\
\hline 10 & $\begin{array}{l}\text { Written from the perspective of the competition (mentions about the } \\
\text { competition) }\end{array}$ & 14.19 \\
\hline 11 & Quoting an example that illustrates the lack of ethics in business & 12.16 \\
\hline 12 & $\begin{array}{l}\text { Indicating the relativism of ethics (what is ethical for some is not necessarily } \\
\text { so for others) }\end{array}$ & 12.16 \\
\hline 13 & $\begin{array}{l}\text { Stressing that ethics can become a tool to gain and maintain valuable } \\
\text { employees and contractors / reputation / trust }\end{array}$ & 11.49 \\
\hline 14 & Presenting the advantages of being unethical & 10.81 \\
\hline 15 & Presenting the disadvantages of being unethical & 10.14 \\
\hline 16 & Being both "for" and ",against” ethics & 7.43 \\
\hline 17 & Claiming that business ethics does not exist & 4.73 \\
\hline
\end{tabular}




\begin{tabular}{r|l|c}
\hline 18 & Indicating that large companies are often less ethical than small enterprises & 3.38 \\
\hline $\mathbf{1 9}$ & Referring to the issue of ethics to the environment - sustainable development & 3.38 \\
\hline $\mathbf{2 0}$ & Presenting the disadvantages of being ethical & 2.70 \\
\hline $\mathbf{2 1}$ & Claiming that abiding by the law is enough to be ethical & 2.70 \\
\hline 22 & Indicating lack of ethical education & 1.35 \\
\hline 23 & Being "against" ethics & 0.00 \\
\hline
\end{tabular}

Source: own study based on research results

Referring to the factors influencing ethical choices and behavior of members of the organization, as presented in Figure 1, note that in the light of the results obtained, every fourth respondent $(23.65 \%)$ indicated that the use of ethics means establishing and observing moral principles in the company, with some expressing opinions that these rules should be included in the organization's code of ethics. In the meantime, almost a fifth of (18.24\%) of the respondents could recognize the importance of ethics in individual business activity. Looking for any patterns in the opinions expressed on the issues in question, further analyses were performed taking into account the characteristics differentiating the respondents (gender and field of study). The observed differences are presented in table $2^{3}$.

The data contained in table 2 shows that women were almost three times more likely than men (a difference of 12.67 percentage points) to stress the importance and impact on personal ethics on the overall business activity. This perspective on the issue of ethics may be a reflection of the fact that women more often than men tend to be interested in their own identity and relationships with other people (Bliss et al. 2003; Kupczyk 2009; Lisowska et al. 2000; Powell, Graves 2003; Szymborski 2005). In addition, they are usually more sensible toward others than men (also in terms of ethical decisions and their sources), which is probably due to cultural background (Kupczyk 2009). Women are context-oriented in their thinking, recognizing the issues and aspects to a greater extent than men, whereas women occupying managerial positions, more often than men, employ emotional intelligence and empathy in their work (Fisher 2003; Kupczyk 2009).

3 Apart from the indications of the respondents expressed as a percentage, the table also contains the difference in value between the responses, expressed in percentage points. 
A characteristic feature of women in business is taking care of human interactions and openness to diversity (Kupczyk 2006). These differences between men and women occur regardless of one's personal or professional life situation - they therefore also affect the perception of ethics in business.

Table 2. Respondents' opinions about the importance of personal ethics and the need to codify ethics, depending on gender and field of study (in \%)

\begin{tabular}{c|c|c|c|c}
\hline \multirow{2}{*}{$\begin{array}{c}\text { Respondents' } \\
\text { characteristics }\end{array}$} & \multicolumn{2}{|c|}{$\begin{array}{c}\text { Recognition of the importance of } \\
\text { personal ethics }\end{array}$} & \multicolumn{2}{|c}{$\begin{array}{c}\text { Indication that use ethics means } \\
\text { establishing and complying with the rules }\end{array}$} \\
\cline { 2 - 2 } & $\begin{array}{c}\text { \% of the } \\
\text { responses }\end{array}$ & $\begin{array}{c}\text { Difference in } \\
\text { percentage points }\end{array}$ & \% of the responses & $\begin{array}{c}\text { Difference in } \\
\text { percentage points }\end{array}$ \\
\hline Women & 21.24 & \multirow{2}{*}{12.67} & 25.66 & \multirow{2}{*}{8.52} \\
\cline { 2 - 2 } Men & 8.57 & & 17.14 & \multirow{2}{*}{5.50} \\
\hline Management & 27.12 & \multirow{2}{*}{14.76} & 20.34 & \\
\hline Economics & 12.36 & & 25.84 & \\
\hline
\end{tabular}

Source: own study based on research results

It was also found that, in comparison with those studying toward a degree in Management, the students of Economics talked about the importance of personal ethics in business twice less (difference in percentage points was, in this case, 14.76). The differences observed are associated not only with the scope and perspective of teaching characteristic for each of the fields of study, but are also due to differences of personal background, different educational environments, different educational paths and interests, all influencing the ultimate career choice.

In the case of the second analyzed category of the responses, i.e. indicating the need to codify ethics in the company, there were no significant differences in opinion between men and women or students of Economics and Management. It is also worth noting that none of the respondents drew attention to the relationship between organizational culture and manifestation of ethical or unethical behavior by organization members.

The analysis results showed that ethics in business is crucial for young people, the representatives of Generation Y. This has been confirmed by numerous studies on the values important for that generation. For example, the authors of "The Millennial Survey 2014" (Czego oczekuje... 2016) believe that the 
representatives of Generation Y wish to work in companies that comply with the required ethical standards. They argue that business success should be measured not only in terms of financial performance, but also the extent to which it affects society's quality of life. In their view, this should be one of the main objectives of any business activity. Generation $Y$ are interested in charity work and want to participate in "public life". According to another study - "Y-greki w pracy i... o pracy" - those starting their career tend to expect from their employers, above all, respect for employees and business partners, sincerity and transparency, as well as fair conduct from their direct supervisor ${ }^{4}$. This characteristic contrasts the stereotypical thinking about Generation Y, often referred to as „young, talented, disloyal ...". It is believed they expect constant praise and highest ratings, even if they do not excel. They focus on their personal needs (Podwysocki 2016). Some studies confirm that "Generation Y people are very demanding employees. They expect their employer to facilitate their intensive development, present them with professional challenges, offer them a clear career path and the balance between work and personal life. However, high self-esteem and awareness of their education level often means that they often have high salary expectations, which prompts them to show a demanding attitude towards the employer. It can also be noticed that Generation $Y$ exhibit little loyalty and general aversion to the standards and principles dictated by the company" (Pokolenie X, Y... 2016).

\section{Final remarks}

The presented image of Generation Y, outlined based of various studies, demonstrates a lack of cohesion among the community in question. It was aptly put by J.A. Fazlagić (2016), who wrote that: „[...] representatives of the Polish Generation Y are kind of a hybrid of the system of values characteristic of their Western counterparts, and traditional Eastern European, Slavic values". From the standpoint of the above considerations, it should be emphasized that young people recognize the need to manifest ethical behavior in business, but not always realize that the man-made moral choices in the workplace have their origins, among others, in their personal ethics. Perhaps they are aware that in the economic practice, ethical conduct required from the employees, introduced

4 Research report for "Y-greki w pracy i... o pracy", conducted by the research agency 4P Research Mix on behalf of Henkel Poland in September 2015. The aim of the study was to learn about the expectations of the youngest generation of workers and students entering the labor market toward current and future employers (To etyczne firmy... 2016). 
by company boards, are often supported solely by sanctions resulting from the hierarchical nature of enterprises. This is a mistake because „if the standards set out in the company's ethical declaration are not the content of specific psychological experiences of employees, characteristic of moral norms, it can be said that from the point of view of the mode of control of organizational behavior, we are dealing with a phenomenon bordering on formal tools of management and custom - management due to the authoritative mode of implementation, and custom due to mechanical subordination of the individual (as per response to the question about what one is expected to do or not do, rather than what is perceived as wrong or unjust)" (Szczupaczyński 2014). Formalized standards of ethical conduct in the company should therefore - where possible - refer to the moral attitudes of employees (Stankiewicz, Łychmus 2011a; Stankiewicz et al 2011; Stankiewicz, Łychmus 2011b; Stankiewicz, Łychmus 2010; Stankiewicz, Łychmus 2009; Bortnowska et al. 2009; Stankiewicz et al. 2009; Stankiewicz, Łychmus 2009; Stankiewicz, Łychmus 2008a; Stankiewicz, Łychmus 2008b; Stankiewicz et al. 2008; Stankiewicz, Łychmus 2007). There is then a chance that the actions they opt for in fulfilling their duties and organizational roles will be accompanied by certain emotions, resulting from the evaluation of good and evil, as well as the characteristic type of mental sanctions associated with moral phenomena (sense of inner conflict, remorse, guilt ). Individuals who declare certain moral principles feel the inner need to use it or at least the need to have credible reasons for their abandonment (Szczupaczyński 2014). The mere approval of organization members, e.g. of the rule of fair competition rules or confidentiality, is not enough - they should also know what the implementation of these principles should be about (Goodell 1994; Lewicka-Strzałecka 1999; Lewicka-Strzałecka 2001). And this is where institutionalization of ethics in the company comes in. Creating favorable conditions for making ethical choices by organization members therefore requires knowledge of the values and standards of conduct they follow. It also calls for creating and using the system that takes them into account and codifies rules of ethical behavior in the company.

\section{Summary}

\section{Ethical choices and behavior of young people in the organization; influencing factors}

The main focus of an article became the answers to questions: what factors control the behavior of people involved in business activities in a situation of choice between ethical and cost-effective action, and how important is ethics of individuals when they are 
making this kind of decision? From this perspective interesting are those who "have not yet entered the labor market", and therefore their individual ethics has not been subjected to the pressure of business practice in its ethical and unethical dimension. What are their opinions on business ethics? What values in business are important to them?

Keywords: ethics, ethical behavior, individual ethics, ethical choices.

\section{Streszczenie}

Wybory etyczne i zachowania młodych w organizacji; czynniki je kształtujące

Celem artykułu jest udzielenie odpowiedzi na pytania: jakie czynniki decydują o zachowaniu ludzi zaangażowanych w działalność gospodarczą w sytuacji wyboru między działaniem etycznym a opłacalnym oraz, jakie znaczenie ma etyka indywidualna jednostek przy podejmowaniu tego rodzaju decyzji? Z tej perspektywy interesujące są osoby, które „jeszcze nie weszły na rynek pracy", a zatem ich etyka indywidualna nie została poddana presji praktyki gospodarczej w jej etycznym i nieetycznym wymiarze. Jakie są ich opinie na temat etyki biznesu? Jakie wartości w biznesie są dla nich ważne?

\section{Słowa}

kluczowe: etyka, zachowania etyczne, etyka indywidualna, wybory etyczne.

\section{References}

1. Bliss R.T., Polutnik L., Lisowska E. (2003), Women Business Owners and managers in Poland, [in:] New Perspective on Women Entrepreneurs, red. J.E. Butler, Information Age Publishing Inc., Greenwich.

2. Borkowski T. (2009), Filozoficzne i pragmatyczne ograniczenia etyki biznesu, "Annales. Etyka w życiu gospodarczym" Vol. 12, No. 1.

3. Bortnowska H., Łychmus P., Stankiewicz J. (2009), Możliwości wykorzystania technik szkoleniowych celem upowszechniania etyki podczas kształcenia pracowników, [in:] Przedsiębiorstwo w warunkach globalnej konkurencji, (eds.) A. P. Balcerzak, E. Rogalska, Wydaw. Adam Marszałek, Torun.

4. Coraz więcej kobiet w nauce... (2016), http://www.edulandia.pl/ studia/1,118573,15945557, Coraz wiecej kobiet w nauce Na_studiach_ dziewczyny.html (30.04.2016 - access date). 
5. Czego oczekuje pokolenie Y (2016), http:/ / it-manager.pl/czego-oczekujepokolenie-y/ (01.04.2016 - access date).

6. Fazlagić J.A. (2016), Charakterystyka pokolenia Y, http://www.e-mentor. edu.pl/artykul/index/numer/25/id/549 (29.03.2016 - access date).

7. Fisher H. (2003), Pierwsza pleć. Jak wrodzone talenty kobiet zmieniaja nasz świat, Wydaw. Jacek Santorski \& Co, Warszawa.

8. Fleming J. S. (2016), Piaget, Kohlberg, Gilligan, and Others on Moral Development, http://swppr.org/Textbook/Ch\%207\%20Morality.pdf (30.04.2016 - access date).

9. Gasparski W. (2000), Wykłady z etyki biznesu, Wyd. Wyższej Szkoły Przedsiębiorczości i Zarządzania im. Leona Koźmińskiego, Warszawa.

10. Gasparski W. (2004), Wyktady z etyki biznesu. Nowa edycja, Wyd. Wyższej Szkoły Przedsiębiorczości i Zarządzania im. Leona Koźmińskiego, Warszawa.

11. Generacja Y - czym jest i co ja wyróżnia? (2016), http://praca.wp.pl/ title,Generacja-Y-czym-jest-i-co-ja-wyroznia,wid,14347184,wiadomosc. html (29.03.2016 - access date).

12. Goodell R. (1994), Ethics in American Business: Policies, Programs and Perceptions, Ethics Recource Center, Washington.

13. Klimczak B. (2003), Etyka gospodarcza, Wydawnictwo Akademii Ekonomicznej im. Oskara Langego, Wrocław.

14. Klimczak B. (1999), Moralna odpowiedzialność przedsiębiorcy, „Annales. Etyka w życiu gospodarczym", Vol. 2.

15. Kopycińska D. (2001), Etyka biznesu - sukces czy wielka niewiadoma? [in:] Etyka biznesu jako przedmiot nauczania, (ed.) W. Gasparski, A. LewickaStrzałecka, Wyd. Wyższej Szkoły Przedsiębiorczości i Zarządzania im. Leona Koźmińskiego, Warszawa.

16. Kubik K. (2013), Rola menedżera w kształtowaniu etycznych zachowań pracowników w organizacji, Zeszyty Naukowe Uniwersytetu PrzyrodniczoHumanistycznego w Siedlcach, Seria: Administracja i Zarządzanie No. 98.

17. Kupczyk T. (2009), Kobiety w zarządzaniu i czynniki ich sukcesów, Wyd. Wyższej Szkoły Handlowej, Wrocław.

18. Kupczyk T. (2006), Uwarunkowania sukcesu zawodowego w opinii kadry kierowniczej przedsiębiorstw z Dolnego Ślaska, [in:] Listwan T. (ed.), Sukces w zarządzaniu kadrami. Kapitał ludzki w organizacjach międzynarodowych, Wydaw. Akademii Ekonomicznej we Wrocławiu.

19. Leszkowicz-Baczyński J., Szaban D. (2014), Wizerunek Uniwersytetu Zielonogórskiego, ocena efektów kształcenia oraz własnej aktywności ekonomicznej w przekonaniach absolwentów. Edycja 2014.

20. Lewicka-Strzałecka A. (1999), Etyczne standardy firm i pracowników, Wyd. IFiS PAN, Warszawa.

21. Lewicka-Strzałecka A. (1997), Etyka biznesu jako dyscyplina naukowa, [in:] J. Dietl, W. Gasparski (eds.), Etyka biznesu, PWN, Warszawa. 
22. Lewicka-Strzałecka A. (2001), Poznawczy model kształcenia etycznego: studium przypadku [in:] Etyka biznesu jako przedmiot nauczania, (eds.) W. Gasparski, A. Lewicka-Strzałecka, Wyd. Wyższej Szkoły Przedsiębiorczości i Zarządzania im. Leona Koźmińskiego, Warszawa.

23. Lewicka-Strzałecka A. (2006), Społeczna odpowiedzialność biznesu w Polsce: ograniczenia i perspektywy, "Annales. Etyka w życiu gospodarczym” 2006, Vol. 9, No. 1.

24. Lisowska E., Bliss R., Polutnik L., Lavelle J. (2000), Polskie menedżerki 2000 i ich porównanie z amerykańskimi, Kobieta i Biznes 2000, No. 1-2.

25. Łychmus P. (2014), Raport z monitoringu karier zawodowych absolwentów Wydziału Ekonomii i Zarzadzania, Edycja 2014.

26. Mesjasz J. (2003), Wartości a psychologiczne koszty sukcesu zawodowego menedżerów, [in:] Witkowski S. (ed.) Psychologiczne wyznaczniki sukcesu w zarządzaniu. Tom VI. Prace Psychologiczne LVII Uniwersytetu Wrocławskiego.

27. Nogalski B., Śniadecki J. (2001), Etyka zarządzania przedsiębiorstwem, Oficyna Wydawnicza Ośrodka Postępu Organizacyjnego, Bydgoszcz.

28. Podwysocki P. (2016), Zrozumieć pokolenie Y, http://naszeinspiracje.com/ tematyka/dobry-wplyw/zrozumiec-pokolenie-y/ (01.04.2016 - access date).

29. Pokolenie X, Y na rynku pracy (2016), https://kariera.sgh.waw.pl/ artykuly/spoleczenstwo/pokolenie-x-y-na-rynku-pracy (01.04.2016 access date).

30. Porębski Cz. (1997), Czy etyka się optaca? Zagadnienia etyki biznesu, Wyd. Znak, Kraków.

31. Powell G.N., Graves L.M. (2003), Women and Men In Management, 3rd ed. Sage Publication, Thousand Oaks.

32. Ryan L.V., Sójka J. (1997), Etyka biznesu, Wyd. W drodze, Poznań.

33. RybakM.(2004),Etykamenedżera:społecznaodpowiedzialnośćprzedsiębiorstwa, Wyd. Naukowe PWN, Warszawa.

34. Siegal M. (2016) Kohlberg versus Piaget: to what extent has one theory eclipsed the other? Merrill-Palmer Quarterly of Behavior and Development, Vol. 26, No. 4, https://www.jstor.org/stable/23084039?seq=1\#page_ scan_tab_contents (30.04.2016 - access date).

35. Stankiewicz J., Łychmus P. (2008), A code of ethics: a company's philosophy or a list of deontological obligations of an employee?, "Management", Vol. 12, No. 1.

36. Stankiewicz J., Łychmus P., Bortnowska H. (2009), Kodeks etyczny istotnym instrumentem chroniacym bezpieczeństwo informacji $w$ mikro- lub matym przedsiębiorstwie, [in:] Prace Naukowe Uniwersytetu Ekonomicznego we Wrocławiu, No. 49.

37. Stankiewicz J., Łychmus P., Bortnowska H. (2011), Szanse upowszechniania programów etycznych wśród pracowników bankowych poprzez e-learning, [in:] 
Zeszyty Naukowe Uniwersytetu Szczecińskiego. Ekonomiczne Problemy Usług, No. 660 (74).

38. Stankiewicz J., Łychmus P., Bortnowska H. (2008), Więcej zachowań etycznych podczas zarządzania karierami pracowników $w$ procesie restrukturyzacji przedsiębiorstwa, [in:] Doskonalenie procesu zarządzania przedsiębiorstwem $\mathrm{w}$ obliczu globalizacji: $\mathrm{z}$ teorii i praktyki, (eds.) R. Borowiecki, A. Jaki, Katedra Ekonomiki i Organizacji Przedsiębiorstw Uniwersytetu Ekonomicznego w Krakowie, Kraków.

39. Stankiewicz J., Łychmus P. (2009), Forming the skills of adjudicating ethical dilemmas through cooperation based coaching, "Management", Vol. 13, No. 1.

40. Stankiewicz J., Łychmus P. (2011a), Kodeks etyczny instrumentem upowszechniania $i$ promowania etycznej kultury organizacyjnej wśród pracowników, [in:] Zeszyty Naukowe Ostrołęckiego Towarzystwa Naukowego im. Adama Chętnika, Ostrołęka.

41. Stankiewicz J., Łychmus P. (2009), Ksztattowanie wizerunku zewnętrznego przedsiębiorstwa jako pracodawcy poprzez etyczne zarzadzanie personelem, [in:] Prace Naukowe Uniwersytetu Ekonomicznego we Wrocławiu, No. 43.

42. Stankiewicz J., Łychmus P. (2008b), Kształtowanie zachowań etycznych pracowników, [in:] Koncepcje zarządzania jakością: doświadczenia i perspektywy, (ed.) T. Sikora, Wydaw. Naukowe PTTŻ, Kraków.

43. Stankiewicz J., Łychmus P. (2011b), Upowszechnianie etycznej kultury organizacyjnej w przedsiębiorstwie za pomoca programu etycznego, [in:] Zeszyty Naukowe Wyższej Szkoły Bankowej we Wrocławiu, No. 24.

44. Stankiewicz J., Łychmus P. (2010), Upowszechnienie wartości $i$ norm społecznych wśród pracowników z wykorzystaniem kodeksu etycznego, [in:] Zeszyty Naukowe Wyższej Szkoły Bankowej we Wrocławiu, No. 19.

45. Stankiewicz J., Łychmus P. (2007), Wspieranie zmian kultury organizacyjnej poprzez programy etyczne przedsiębiorstw, [in:] Prace Naukowe Akademii Ekonomicznej im. Oskara Langego we Wrocławiu, No. 1184.

46. Sternberg E. (1998), Czysty biznes. Etyka biznesu w działaniu, tłum. P. Łuków, Wyd. Naukowe PWN, Warszawa.

47. Sułek M., Świniarski J. (2001), Etykajako filozofia dobrego działaniazawodowego. Podręcznik akademicki, Dom Wydawniczy Bellona, Warszawa.

48. Szczupaczyński J. (2014), Kodeksy etyczne i ich wpływ na moralne perspektywy polskich menedżerów, Acta Universitatis Lodziensis, folia Sociologica 48.

49. Szulczewski G. (2008), http://www.cebi.pl/texty/wyklady1.doc (01.04.2008 - access date).

50. Szymborski K. (2005), Mózg płci, Polityka, No. 6.

51. To etyczne firmy przyciągną Y-greki. Wyniki badania na zlecenie Henkel Polska (2016), http://osobyzasoby.pl/2015/10/to-etycznefirmy-przyciagna-y-greki-wyniki-badania-na-zlecenie-henkel-polska/ (01.04.2016 - access date). 
52. Tomczyk-Tołkacz J. (2000), Człowiek w biznesie - między pragnieniem pieniądza a cnota, „Annales. Etyka w życiu gospodarczym”, Vol. 3.

53. Turek J. (1999), Normy etyczne - niedoceniony kapitat w gospodarce wolnorynkowej, „Annales. Etyka w życiu gospodarczym”, Vol. 2.

54. Wiśniewski R. (1997), Trzy typy teorii etycznych a etyka biznesu, [in:] J. Dietl, W. Gasparski (eds.), Etyka biznesu, PWN, Warszawa.

55. Zadroga A. (2009), Metody ujmowania etyki biznesu w Polsce, "Annales. Etyka w życiu gospodarczym", Vol. 12, No. 1. 